\title{
ALDOSTERONE EXCRETION IN NORMAL SUBJECTS DEPLETED OF SODIUM AND POTASSIUM ${ }^{1}$
}

\author{
By BEN B. JOHNSON, AMOS H. LIEBERMAN, ${ }^{2}$ AND PATRICK J. MULROW 3 \\ (From the Department of Medicine, Stanford University School of Medicine, \\ San Francisco, Calif.)
}

(Submitted for publication October 30, 1956; accepted February 7, 1957)

Aldosterone has recently been identified in adrenal cortical extracts (1) and in human urine $(2,3)$ as the principal steroid affecting electrolyte balance. The physiological mechanisms controlling the release of aldosterone are not completely understood (4). A number of different mechanisms and stimuli have been suggested (5-12) as important in the regulation of aldosterone secretion.

In normal subjects on diets which were normal except for decreased sodium content, aldosterone output in the urine has been previously shown to be increased $(3,13)$; whereas sodium loading in subjects on otherwise normal diets results in decreased output of aldosterone (14). A rise in aldosterone output has been observed during potassium loading in man (14). In rats fed a low potassium diet, the aldosterone content of adrenal venous blood was decreased (8). Human aldosterone output after potassium withdrawal from the diet has not been previously studied.

The present study was designed to determine: 1) whether low potassium intake has any effect on aldosterone output in man, 2) whether low potassium intake can prevent the increase in aldosterone output that regularly follows sodium depletion, and if so, 3 ) whether potassium replacement during continued sodium deprivation results in a rise in aldosterone output.

\section{EXPERIMENTAL PROCEDURE AND METHODS}

Foods of low sodium and potassium content were selected to provide the experimental diet consisting of two alternate menus of three meals per day. The diet was supplemented with a multivitamin capsule daily and with

1 This investigation was supported by a research grant (A-630) from the National Institute of Arthritis and Metabolic Diseases, Public Health Service.

2 Trainee of the National Institute of Arthritis and Metabolic Diseases, Public Health Service.

3 Postdoctoral Research Fellow, National Cancer Institute, Public Health Service. calcium caseinate as additional protein. At each meal foods were weighed, and fluids were measured to give the following composition, based on calculation from standard tables:

Menu I-2,200 calories (P 79, F 84, C 242, ethanol 20), sodium $9 \mathrm{mEq}$., potassium $9 \mathrm{mEq}$.

Menu II-2,225 calories (P 71, F 68, C 287, ethanol 20), sodium $9 \mathrm{mEq}$, potassium $9 \mathrm{mEq}$.

The diet was essentially the same as used by earlier workers (15), except for lower total calories and sodium content.

The subjects for the experiment were three men in good health, who ate the experimental diet for 26 consecutive days. In each of the three subjects the study was divided into four successive periods according to the following plan:

1. Control (4 days)-Sodium chloride and potassium acetate, bicarbonate and citrate were added to the diet to give a total daily intake of sodium $145 \mathrm{mEq}$. and of potassium, $85 \mathrm{mEq}$.

2. Potassium depletion (10 days)-Potassium supplements were omitted to give a total daily intake of sodium $145 \mathrm{mEq}$. and potassium $9 \mathrm{mEq}$.

3. Combined depletion ( 7 to 8 days)-Sodium supplement was also omitted to give a total daily intake of sodium $9 \mathrm{mEq}$. and potassium $9 \mathrm{mEq}$. On the sixth and seventh days one subject took $150 \mathrm{mEq}$. of ammonium chloride.

4. Potassium replacement (4 days)-Supplementary potassium was added to the basic diet to give a total daily intake of sodium $9 \mathrm{mEq}$. and potassium $99 \mathrm{mEq}$.

The supplementary sodium or potassium was taken with food and was divided as evenly as possible among the three meals. The daily potassium intake during the period of potassium replacement was slightly higher than during the control period in order not to prolong repair of the potassium deficit and because the higher dose was more convenient to measure. A measured amount of distilled water was added to the dietary fluids each day to maintain the total water intake between 2.3 and 2.7 liters, except in a few instances during the first two periods when variation in individual daily fluid intake from 1.7 to 3.4 liters was allowed.

The subjects were weighed each day, and daily total collections of urine were made. At the end of each dietary period and at intervals throughout the experiment, blood samples were drawn without stasis into syringes containing heparin. Chloride in plasma and 
TABLE I

Sodium and potassium in urine and plasma; changes in body weight

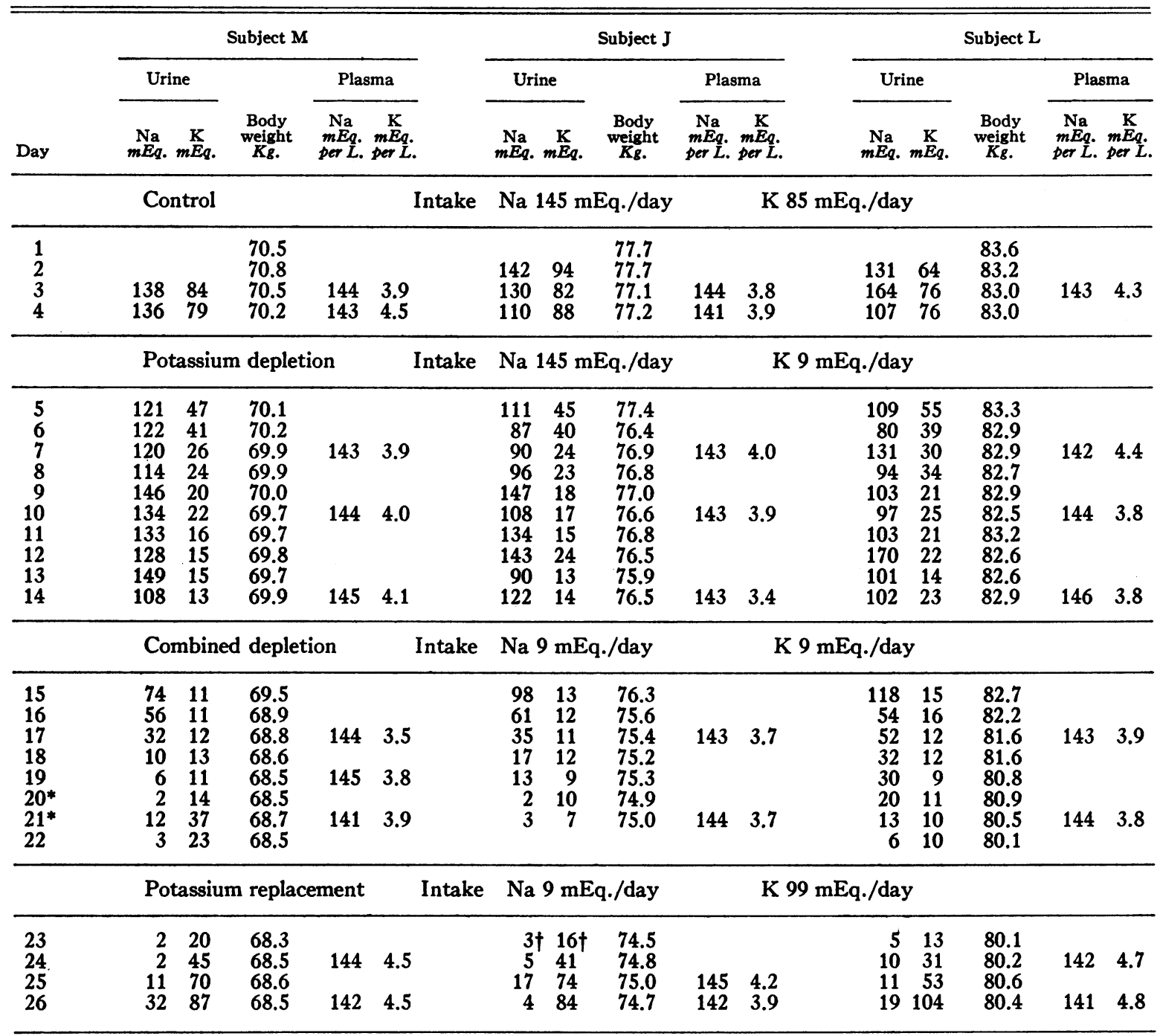

* One hundred and fifty mEq. of $\mathrm{NH}_{4} \mathrm{Cl}$ added to diet.

$\dagger$ Potassium replacement in subject $J$ was started on day 22.

urine was determined by the method of Schales and Schales (16), plasma $\mathrm{CO}_{2}$ content by the Van Slyke and Neill manometric method (17), and total protein by the biuret reaction (18). Creatinine chromogens in plasma and urine were measured by the method of Bonsnes and Taussky (19), sodium and potassium by flame photometry using a lithium internal standard. Urine $\mathrm{pH}$ and titratable acidity were determined with the glass electrode $\mathrm{pH}$ meter, urine being titrated to $\mathrm{pH}$ 7.4; and urine ammonia was measured by the method of Van Slyke and Cullen as modified by Hawk, Oser, and Summerson (20). The 17-ketosteroids in urine were measured according to Drekter's modification (21) of the method of Holtorf and Koch; and 17-hydroxycorticos- teroids by a modification of the method of Silber and Porter (22).

For estimation of aldosterone output, urine was acidified to $\mathrm{pH} \mathrm{1,} \mathrm{and} \mathrm{a} \mathrm{chloroform} \mathrm{extract} \mathrm{was} \mathrm{made} \mathrm{im-}$ mediately. After 24 hours a second chloroform extract was made (23); this was fractionated by paper chromatography in toluene-propylene glycol. The fraction containing aldosterone was eluted and assayed in adrenalectomized rats (24). Response of the rats to the aldosterone fraction has been calculated from the observed increase in ratio of potassium to sodium output, expressed in micrograms of the desoxycorticosterone acetate (DCA) standard required for an equivalent effect. Crystalline aldosterone has averaged 36.5 times the ac- 
TABLE II

Effects of ammonium chloride administration on electrolyte output in urine during sodium and potassium depletion

\begin{tabular}{|c|c|c|c|c|c|c|c|}
\hline Day & $\begin{array}{c}\text { Volume } \\
\text { ml./24 hrs. }\end{array}$ & $\mathrm{pH}$ & $\underset{m E q . / 24 \text { hrs. }}{\text { Sodium }}$ & $\underset{m E q . / 24 \text { hrs. }}{\text { Potassium }}$ & $\underset{m E q . / 24 \text { hrs. }}{\text { Ammonium }}$ & $\begin{array}{c}\text { Titratable } \\
\text { acid } \\
m E q . / 24 \text { hrs. }\end{array}$ & $\begin{array}{c}\text { Chloride } \\
m E q . / 24 \text { hrs. }\end{array}$ \\
\hline \multicolumn{8}{|c|}{ Diet: Na $9 \mathrm{mEq} . / 24$ hrs. $\mathrm{K} 9 \mathrm{mEq} . / 24 \mathrm{hrs}$. } \\
\hline $\begin{array}{l}18 \\
19\end{array}$ & $\begin{array}{l}1,770 \\
1,970\end{array}$ & $\begin{array}{l}6.29 \\
6.44\end{array}$ & $\begin{array}{l}9.9 \\
6.0\end{array}$ & $\begin{array}{l}12.7 \\
11.4\end{array}$ & $\begin{array}{l}49.5 \\
48.8\end{array}$ & $\begin{array}{r}13.3 \\
9.7\end{array}$ & $\begin{array}{l}22.3 \\
16.4\end{array}$ \\
\hline \multicolumn{8}{|c|}{ Diet: $\mathrm{Na} 9 \mathrm{mEq} . / 24$ hrs. $\mathrm{K} 9 \mathrm{mEq} . / 24 \mathrm{hrs} . \quad \mathrm{NH}{ }_{4} \mathrm{Cl} 150 \mathrm{mEq} . / 24 \mathrm{hrs}$. } \\
\hline $\begin{array}{l}20 \\
21\end{array}$ & $\begin{array}{l}1,555 \\
2,170\end{array}$ & $\begin{array}{l}6.26 \\
5.75\end{array}$ & $\begin{array}{r}1.7 \\
12.4\end{array}$ & $\begin{array}{l}14.1 \\
36.7\end{array}$ & $\begin{array}{r}67.2 \\
108.5\end{array}$ & $\begin{array}{l}13.0 \\
23.2\end{array}$ & $\begin{array}{r}38.9 \\
113.0\end{array}$ \\
\hline \multicolumn{8}{|c|}{ Diet: $\mathrm{Na} 9 \mathrm{mEq} . / 24 \mathrm{hrs} . \mathrm{K} 9 \mathrm{mEq} . / 24 \mathrm{hrs}$. } \\
\hline 22 & 1,935 & 6.18 & 2.7 & 23.2 & 96.5 & 16.2 & 72.6 \\
\hline
\end{tabular}

tivity of DCA in this bioassay, and this factor was used for calculations of aldosterone output from the bioassay result.

\section{RESULTS}

In Table I the daily output of sodium and potassium in the urine is given for each of the three subjects as well as the plasma concentrations of sodium and potassium and changes in body weight.

\section{Changes in plasma and urine electrolytes}

During the period of potassium depletion (Table I) urine potassium losses initially exceeded potassium intake. The potassium output decreased gradually and by 10 days approached the daily intake level of $9 \mathrm{mEq}$. In all three subjects plasma potassium concentration decreased 0.4 to $0.5 \mathrm{mEq}$. per L. below the last control determination. The minimum potassium deficit during the 10-day period, calculated from dietary intake and urine loss, was of the order of 150,145 , and $195 \mathrm{mEq}$. in subjects $M, J$, and $L$, respectively.

Sodium excretion decreased initially below control levels in all three subjects, but after four days tended to return toward control values in subjects $M$ and $J$. The subjects appeared to retain approximately 95,140 , and $250 \mathrm{mEq}$. of sodium, respectively, in 10 days, estimated from urinary sodium output during the control period on the same intake of sodium. Plasma sodium concentration did not change strikingly (Table I); a decrease of 1.2 to 3.6 per cent in hematocrit was observed in the three subjects.

During combined depletion of sodium and potassium, urinary sodium output fell below the in- take of $9 \mathrm{mEq}$. by the fifth, sixth, and eighth days, respectively, in subjects $M, J$, and $L$. At this time the minimum sodium deficit, calculated from dietary intake and urine losses, was of the order of 130,160 , and $250 \mathrm{mEq}$., respectively, in subjects $\mathrm{M}, \mathrm{J}$, and L. A sharp decrease in body weight was observed early in this period, and there was a slight rise in hematocrit $(4.6,2.3$, and 5.1 per cent) and in plasma proteins $(0.3,0.2$, and 1.1 $\mathrm{Gm}$. per cent). Potassium output in the urine decreased further. In one subject the $U / P$ ratio for potassium reached 1.0 at a urine and plasma concentration of $3.7 \mathrm{mEq}$. per L. on the seventh day of combined depletion. Plasma potassium continued to fall in subject $M$ and remained below control levels in all subjects (Table I). The calculated minimum deficit of potassium increased only very slightly, about 15,2 , and $25 \mathrm{mEq}$., respectively, during combined depletion of sodium and potassium. Extra-renal losses of potassium were not measured, and the period of ammonium chloride administration in subject $M$ was not included in the above calculation.

Ammonium chloride in a dose of $150 \mathrm{mEq}$. per day was administered to subject $M$ on the sixth and seventh days of the combined sodium and potassium depletion period. Results of urine electrolyte determinations in this subject for the last five days of the period are shown in Table II. No change in body weight occurred during the administration of ammonium chloride. If one assumes a daily loss of 2 per cent of the chloride intake in feces and sweat, there was a retention of approximately $141 \mathrm{mEq}$. of chloride. This was reflected in the increase in plasma chloride from 
108 to $118 \mathrm{mEq}$. per liter. During the second day of ammonium chloride administration there was a marked increase in ammonium excretion and a slight increase in titratable acidity. Sodium excretion remained below intake levels except for an increase to $12 \mathrm{mEq}$. on the second day. Conservation of potassium was less effective, however, urinary potassium rising to $36 \mathrm{mEq}$. on the second day of ammonium chloride administration and to $23 \mathrm{mEq}$. on the day following ammonium chloride administration. The changes in chloride output are closely paralleled by changes in the sum of the cations measured.

Potassium replacement, by the addition of 90 $\mathrm{mEq}$. of potassium salts to the diet, resulted in retention of potassium and a slight increase in sodium excretion. Urine potassium gradually increased and approximated dietary intake by the fourth day. The last two days of this period represent the eleventh and twelfth consecutive days of sodium deprivation; the calculated clearances of endogenous creatinine chromogens were very slightly below control levels in two subjects and 23 and 24 per cent below control levels in subject J.
During 26 days on the diet, there was a net loss of 2.0 to $3.2 \mathrm{Kg}$. in body weight of the three subjects (Table I). The small changes observed in hematocrit, potassium and sodium concentrations in whole blood, and in plasma chloride and total proteins followed no consistent pattern and are not reported in detail. During potassium depletion, plasma $\mathrm{CO}_{2}$ combining power increased by less than $2 \mathrm{mM}$. per liter. Except for the period of ammonium chloride administration in subject $\mathrm{M}$, plasma $\mathrm{CO}_{2}$ values remained within 2.5 , 3.4 , and $2.7 \mathrm{mM}$. per liter of control values in the three subjects.

\section{Changes in adrenocortical steroids}

Aldosterone, 17-ketosteroids, and 17-hydroxycorticosteroids in the urine were within normal limits in all three subjects during the last two days of the control period. Observed values of these steroids throughout the experiment are plotted for each subject in Figures 1, 2, and 3. In Table III the individual aldosterone bioassay results are given with their 95 per cent confidence limits, and the 24-hour output is shown as calculated from

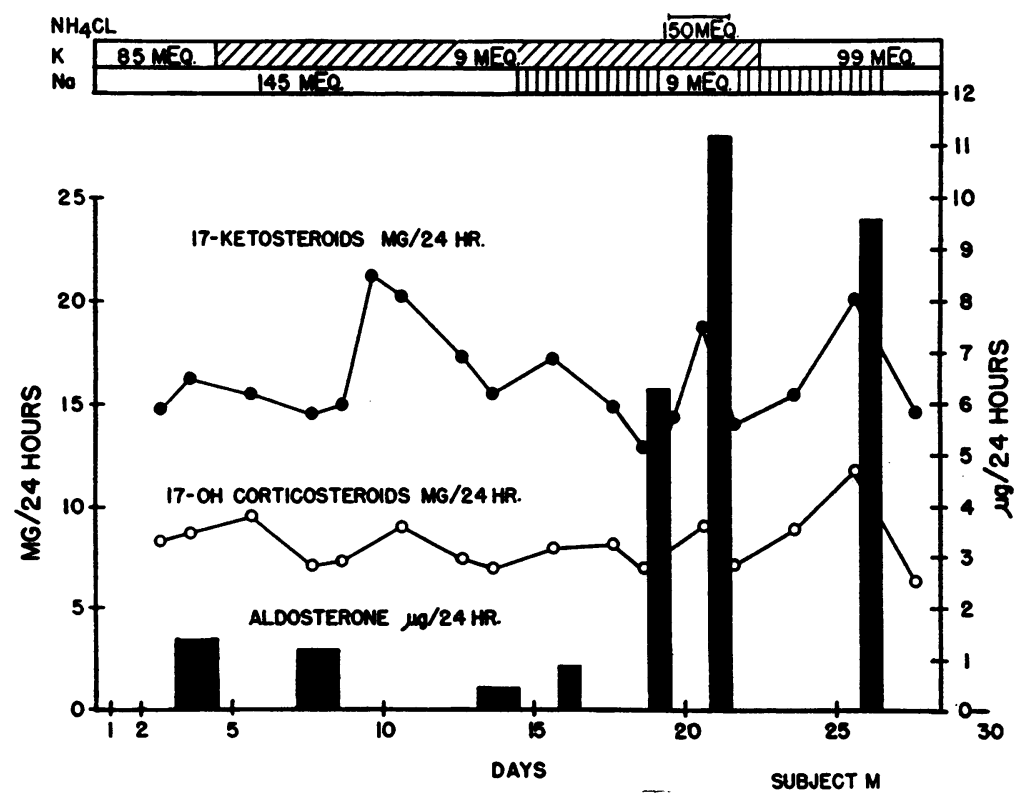

Fig. 1. Steroid Output in Urine of Subject M

The scale for 17-ketosteroid and 17-hydroxycorticosteroid output is on the left, and for aldosterone output on the right. Dietary intake for each period is shown at the top. On the 20th and 21st days of this study, the subject took $150 \mathrm{mEq}$. $\mathrm{NH}_{4} \mathrm{Cl}$, during combined low sodium and low potassium intake. 


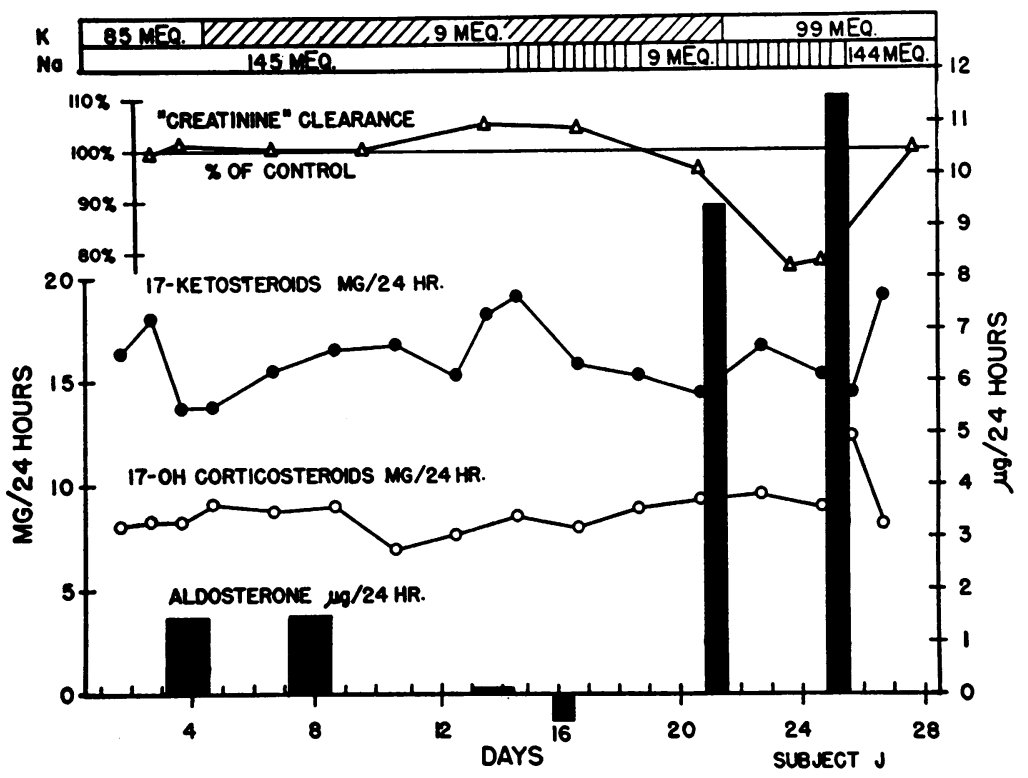

Fig. 2. Sterom Output in Urine of Subject J

Renal clearances of endogenous creatinine are shown in this subject, in whom the changes from control values were larger than in subjects $M$ and $L$.

the quantity of the aldosterone fraction of urine extract used in each assay. On the third and fourth days of potassium depletion, aldosterone output had apparently decreased almost 50 per cent in subject $\mathrm{L}$ but remained at normal levels in the other two subjects. On the ninth and tenth

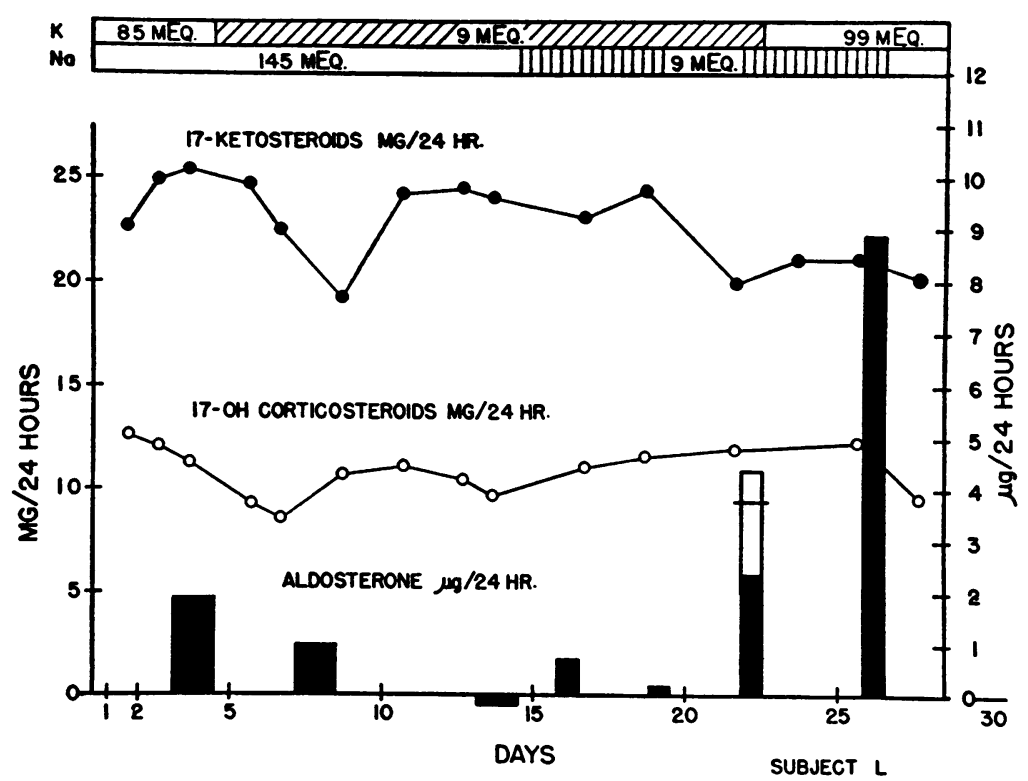

Fig. 3. Steroid Output in Subject L

Two bioassays for aldosterone output on day 22 are indicated by the solid bar and the clear bar above; the best estimate of aldosterone output on this day is shown by the horizontal line in the upper bar, this value being weighted in favor of the higher assay, which was within the dosage range for which the bioassay is standardized. 
TABLE III

Bioassay of aldosterone fraction of urine extract

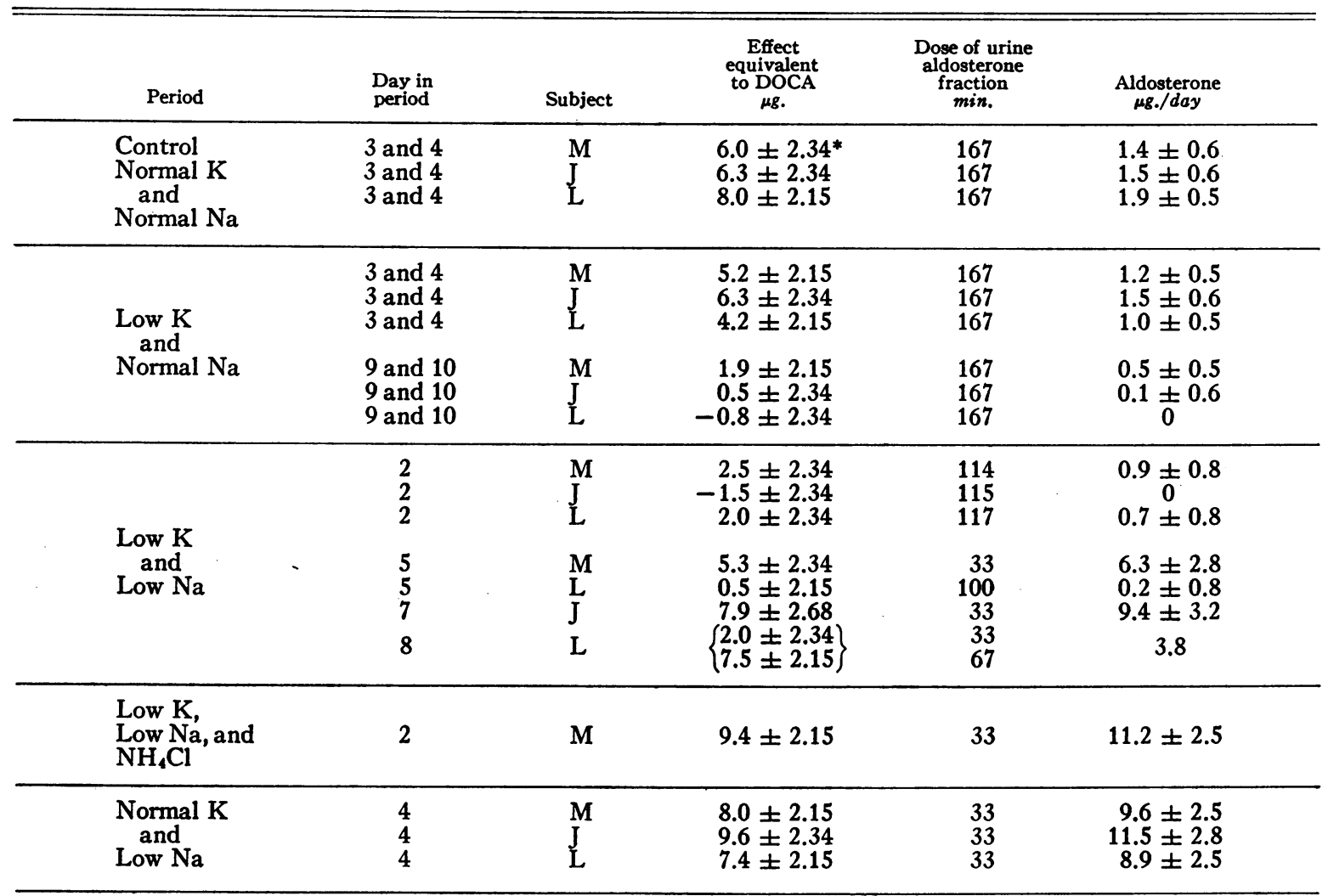

* Ninety-five per cent confidence limits for bioassay.

days of potassium depletion, aldosterone was not detectable in the urine of subject $\mathrm{L}$; aldosterone output in subjects $M$ and $J$ was estimated at very low values, not distinguishable from zero on the basis of 95 per cent confidence limits.

When sodium intake was also reduced during the period of combined depletion, the estimate of urinary aldosterone output on the second day apparently rose slightly in subjects $M$ and $L$ but was not detectable with certainty except in subject $M$. Even in subject $M$ the observed output was below his control level, and there was no evidence of any increase in subject $\mathrm{J}$, whose assay was estimated at zero activity in spite of the fact that a maximal amount of the aldosterone fraction was used for assay. On the fifth day of combined depletion subject $\mathrm{L}$ continued to have urine sodium output greater than the dietary intake, and an aldosterone output that was insignificant. Sodium excretion in the urine had decreased below dietary intake on the fifth, seventh, and eighth days of the period in subjects $M, J$, and $L$, respectively. At this time in each subject the output of aldosterone had increased from the very low levels observed during potassium depletion alone, and was estimated at 2 to 6 times the original control levels.

After four days of potassium replacement, with continued low sodium intake, aldosterone output had risen further in subjects $\mathrm{L}$ and $\mathrm{J}$, with more than a two-fold increase in subject $L$, the apparent increase in subject $\mathrm{J}$ being less than the 95 per cent confidence limits. The highest output of aldosterone in subject $M$ was observed on the seventh day of combined sodium and potassium depletion. This, however, was on the second day of ammonium chloride administration; the effect of ammonium chloride was not studied in the other two subjects. After four days of potassium replacement, subject $M$ appeared to have a slight decrease in aldosterone output from the previous value during ammonium chloride administration, 
but this decrease did not exceed the statistical confidence limits. These estimates of aldosterone output in subject $M$, on the seventh and twelfth days, respectively, of low sodium intake, were significantly above the increase observed on the fifth day of sodium deprivation.

The output of 17-hydroxycorticosteroids and 17-ketosteroids remained within normal limits throughout the experiment (Figures 1 to 3 ); the relatively small fluctuations observed did not appear to have any consistent relationship to the changes in electrolyte intake or to the output of aldosterone.

In Figure 4 the output of aldosterone is plotted against the urinary excretion of sodium, potassium, and the logarithm of the potassium to sodium ratio in the urine. No clear relationship is evident between the output of potassium and aldosterone, but increasing aldosterone output tends to be associated with decreasing urinary sodium. A more direct relationship is apparent between the potassium to sodium ratio in urine and aldosterone output.

\section{DISCUSSION}

These studies demonstrate that low potassium intake can result in decreased output of aldosterone. Even in the presence of low potassium intake, sodium deprivation was followed by a rise in aldosterone output above control levels, but this rise occurred more slowly and did not reach as high levels as those observed during sodium deprivation alone (13). Various physiological stimuli have been proposed as factors in the regulation of aldosterone output. These stimuli include serum potassium concentration $(5,6)$ or potassium to sodium ratio (7), corticotrophin under certain conditions (8-10), and some function of total body sodium (11) or of extracellular fluid volume $(11,12)$. The present experiment provides additional evidence in support of some current concepts of the control of aldosterone output.

The decrease below normal aldosterone output observed during low potassium and normal sodium intake apparently occurred without large net losses of body potassium. The estimated deficit of potassium ranged from about 145 to 195 $\mathrm{mEq}$. in the three subjects, not including losses in feces and sweat. Negative potassium balances of
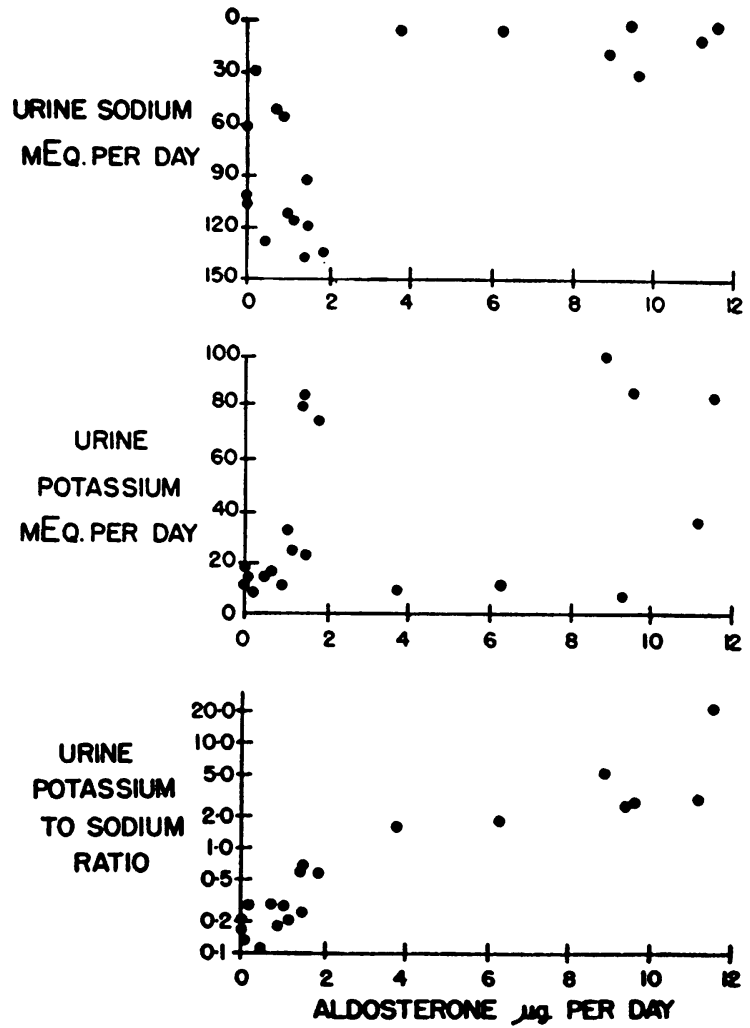

Fig. 4. Aldosterone Output in Relation to the Content of Sodium and Potassium in the Same Urine Collection

A direct relationship is shown between aldosterone output and a logarithmic function of the potassium to sodium output ratio.

267 and $226 \mathrm{mEq}$. have been reported (25) in a normal male subject during two seven-day periods on a diet which was similar, but lower in potassium by 7 to $8 \mathrm{mEq}$. per day. Sodium intake was 173 to $176 \mathrm{mEq}$. per day as compared to 145 $\mathrm{mEq}$. sodium in the present study. These authors further noted positive balances of 569 and $417 \mathrm{mEq}$. of sodium during the two seven-day periods of low potassium intake. Estimated sodium retention was less in the present study; however, it is probable that there was significant positive sodium balance as has been regularly observed in other studies of the effect of low potassium intake in normal subjects $(15,26,27)$. The diminished sodium output in the urine on the third and fourth days of the low potassium period in the present study occurred without an increase in aldosterone output.

Changes either in serum potassium concentra- 
tion or in extracellular fluid volume are possible stimuli resulting in the decreased aldosterone output during low potassium intake. Also, the observed fall in serum potassium might be expected to be correlated with decreased aldosterone output $(5,6)$, but more severe hypokalemia in patients with various diseases has previously been shown to occur without striking changes in the output of aldosterone (28). The usual effect on extracellular fluid volume in normal individuals during potassium depletion appears to be a moderate increase. In two similar studies of low potassium intake, it was concluded from calculations based on the chloride balance that increases in extracellular fluid volume of 1.9 to 3.0 liters (25) and 2.6 and 2.2 liters (26) occurred during potassium depletion with moderately high sodium intake. An increase of inulin space of about 2 to 3.5 liters, and a larger increase in extracellular fluid volume as calculated from chloride balance data, have been shown in six surgical patients maintained postoperatively on potassium-free fluids (29). These patients developed alkalosis within 5 to 19 days, accompanied by a loss of potassium ranging from 180 to $280 \mathrm{mEq}$. There is some evidence $(11,12)$ that acute increases in plasma or extracellular fluid volume may be accompanied by decreased aldosterone output; this would be consistent with the findings during low potassium intake in the present study.

Under the conditions of this experiment the effect of sodium deprivation on aldosterone output appeared to predominate over the opposed effect of low potassium intake. If serum potassium concentration were the primary regulator of aldosterone secretion, as has been suggested (5), the increased output of aldosterone during the period of combined depletion would be expected to follow a rise in serum potassium concentration. During this period the measured plasma potassium concentration remained low or decreased further.

Although aldosterone output increased markedly, combined sodium and potassium depletion appears to have been associated with very small net change in plasma and extracellular fluid volume or in total body sodium. Combined sodium and potassium deprivation after a period of potassium depletion in the similar studies of Womersley and Darragh (25) was accompanied by esti- mated decreases of 1.0 and 1.8 liters in extracellular fluid volume during four and three days, respectively. Net sodium balance was positive in both cases. In the present study, estimated sodium retention in the three subjects of about 95 , 140 , and $250 \mathrm{mEq}$. during potassium depletion was followed by estimated sodium loss during combined sodium and potassium deprivation of about 130,160 , and $250 \mathrm{mEq}$. Although losses via the skin and G.I. tract were not measured, these have been small in comparable studies (30-32), and it is possible that no depletion of total body sodium occurred. The observed increases in hematocrit and plasma protein concentration immediately after sodium withdrawal were no more striking than those usually seen without previous potassium depletion, and suggest that any net change in plasma volume was small.

The continued increases in aldosterone excretion after restoration of potassium to the diet may represent a direct effect of the added potassium or possibly the effect of continued sodium deprivation. The latter seems less likely, since after eight days of combined low sodium and potassium intake, subject $\mathrm{L}$ had only a moderately increased output of aldosterone which was followed by a two-fold increase after four days of potassium replacement with continued sodium restriction. In contrast to the effect of potassium loading in subjects on a normal diet, the increased urine losses of sodium during potassium replacement were very slight and cannot be considered to account for the increase in aldosterone.

Corticotrophin has been shown to produce transient increases in aldosterone output $(4,10)$. It appears unlikely that endogenous corticotrophin played any part in the marked changes in aldosterone output during the present study, since significant variations were not observed in 17-ketosteroid and 17-hydroxycorticosteroid output. Moderate alkalosis has frequently been observed in experimental human potassium depletion (25, 33). Significant changes in plasma $\mathrm{CO}_{2}$ combining power did not occur during the present study except briefly in the subject who was given ammonium chloride. Ammonium chloride administration during depletion of both sodium and potassium resulted in small increases in urine loss of both potassium and sodium, but predominantly of potassium. Aldosterone output rose in the 
absence of any significant loss of sodium or decrease in body weight. Increased aldosterone output has been described after administration of acetazoleamide for one day (34); this was interpreted as due to sodium diuresis and loss of extracellular fluid volume.

Data of the present experiment are not consistent with the hypothesis that all changes in aldosterone secretion are regulated by extracellular fluid volume or by extracellular fluid concentration of sodium or potassium. Little change in total body sodium was produced. Relatively large changes in aldosterone output were observed without striking alterations in the concentration of plasma electrolytes, but the decreases or increases in aldosterone excretion after each change in the diet were in a direction favoring homeostasis of body sodium and potassium.

\section{SUMMARY}

1. In three normal men, restriction of potassium intake to $9 \mathrm{mEq}$. per day was followed by a marked decrease in aldosterone output below control values.

2. When sodium intake was also reduced to $9 \mathrm{mEq}$., aldosterone output rose to levels two to six times the original control values. This rise appeared to be delayed and to fall short of the increases previously observed on deprivation of sodium alone.

3. Restoration of potassium to the diet while sodium restriction was maintained was followed by a slight additional increase in aldosterone excretion in one case, and a moderate increase in the other subjects. The highest aldosterone output of one subject was observed before potassium replacement when $150 \mathrm{mEq}$. ammonium chloride was given for two days.

4. Insignificant changes were observed in the output of 17-ketosteroids and 17-hydroxycorticosteroids.

\section{ACKNOWLEDGMENT}

The authors wish to thank Dr. John A. Luetscher, Jr. for advice and help, and Miss Esther Sippel of the Dietary Department, Stanford University Hospitals, for planning the experimental diet. The technical assistance of $\mathrm{Mr}$. Way Lew, Miss Anne Dowdy, Mrs. Julia Harvey, Mrs. Shirley Cook, and Mr. Lee J. Poo is gratefully acknowledged.

\section{REFERENCES}

1. Simpson, S. A., Tait, J. F., Wettstein, A., Neher, R., v. Euw, J., Schindler, O., and Reichstein, T., Konstitution des Aldosterons, des neuen Mineralocorticoids. Experientia, 1954, 10, 132.

2. Luetscher, J. A., Jr., Neher, R., and Wettstein, A., Isolation of crystalline aldosterone from the urine of a nephrotic patient. Experientia, 1954, 10, 456.

3. Luetscher, J. A., Jr., and Johnson, B. B., Observations on the sodium-retaining corticoid (aldosterone) in the urine of children and adults in relation to sodium balance and edema. J. Clin. Invest., 1954, 33, 1441.

4. Luetscher, J. A., Jr., Aldosterone in Advances in Internal Medicine, W. Dock and I. Snapper, Eds., Chicago, The Year Book Publishers, Inc., 1956, Vol. VIII, pp. 155_203.

5. Laragh, J. H., and Stoerk, H. C., On the mechanism of secretion of the sodium-retaining hormone (aldosterone) within the body. J. Clin. Invest., 1955, 34, 913.

6. Laragh, J. H., Combined Staff Clinic: Mechanisms of edema formation and principles of management. Am. J. Med., 1956, 21, 423.

7. Rosenfeld, G., Rosemberg, E., Ungar, F., and Dorfman, R. I., Regulation of the secretion of aldosterone-like material. Endocrinology, 1956, 58, 255.

8. Singer, B., and Stack-Dunne, M. P., Secretion of aldosterone and corticosterone by the rat adrenal. Nature, 1954, 174, 790.

9. Luetscher, J. A., Jr., Studies of aldosterone in relation to water and electrolyte balance in man in Recent Progress in Hormone Research, G. Pincus, Ed., New York, Academic Press, Inc., 1956, Vol. 12, p. 175.

10. Liddle, G. W., Duncan, L. E., Jr., and Bartter, F. C., Dual mechanism regulating adrenocortical function in man. Am. J. Med., 1956, 21, 380.

11. Beck, J. C., Dyrenfurth, I., Giroud, C., and Venning, E. H., Observations on the regulatory mechanisms of aldosterone secretion in man. Arch. Int. Med., 1955, 96, 463.

12. Bartter, F. C., The role of aldosterone in normal homeostasis and in certain disease states. Metabolism, 1956, 5, 369.

13. Luetscher, J. A., Jr., and Axelrad, B. J., Increased aldosterone output during sodium deprivation in normal men. Proc. Soc. Exper. Biol. \& Med., 1954, 87, 650.

14. Luetscher, J. A., Jr., and Curtis, R. H., Aldosterone: Observations on the regulation of sodium and potassium balance. Ann. Int. Med., 1955, 43, 658.

15. Reimer, A., Schoch, H. K., and Newburgh, L. H., Certain aspects of potassium metabolism. J. Am. Dietet. A., 1951, 27, 1042.

16. Schales, O., and Schales, S. S., A simple and accurate method for the determination of chloride in biological fluids. J. Biol. Chem., 1941, 140, 879.

17. Van Slyke, D. D., and Neill, J. M., The determination 
of gases in blood and other solutions by vacuum extraction and manometric measurement. I. J. Biol. Chem., 1924, 61, 523.

18. Gornall, A. G., Bardawill, C. J., and David, M. M., Determination of serum proteins by means of the biuret reaction. J. Biol. Chem., 1949, 177, 751.

19. Bonsnes, R. W., and Taussky, H. H., On the colorimetric determination of creatinine by the Jaffe reaction. J. Biol. Chem., 1945, 158, 581.

20. Hawk, P. B., Oser, B. L., and Summerson, W. H., Practical Physiological Chemistry. 13th ed., New York, Blakiston Co., 1954, p. 888.

21. Drekter, I. J., Pearson, S., Bartczak, E., and McGavack, T. H., A rapid method for the determination of total urinary 17-ketosteroids. J. Clin. Endocrinol., 1947, 7, 795.

22. Silber, R. H., and Porter, C. C., The determination of 17, 21-dihydroxy-20-ketosteroids in urine and plasma. J. Biol. Chem., 1954, 210, 923.

23. Axelrad, B. J., Cates, J. E., Johnson, B. B., and Luetscher, J. A., Jr., Aldosterone in urine of normal man and of patients with oedema: its increased recovery after hydrolysis with acid and with beta-glucuronidase. Brit. M. J., 1955, 1, 196.

24. Johnson, B. B., Bioassay of adrenal cortical steroids on the basis of electrolyte excretion by rats: Effects of 11-desoxy and 11-oxy-steroids. Endocrinology, 1954, 54, 196.

25. Womersley, R. A., and Darragh, J. H., Potassium and sodium restriction in the normal human. $\mathrm{J}$. Clin. Invest., 1955, 34, 456.

26. Black, D. A. K., and Milne, M. D., Experimental potassium depletion in man. Clin. Sc., 1952, 11, 397.
27. Blahd, W. H., and Bassett, S. H., Potassium deficiency in man. Metabolism, 1953, 2, 218.

28. Lieberman, A. H., Curtis, R., Johnson, B. B., and Luetscher, J. A., Jr., An observation of some factors concerned with aldosterone output. Clin. Research Proc., 1956, 4, 211.

29. Roberts, K. E., Randall, H. T., Philbin, P., and Lipton, $R$., Changes in extracellular water and electrolytes and the renal compensations in chronic alkalosis, as compared to those occurring in acute alkalosis. Surgery, 1954, 36, 599.

30. Freyberg, R. H., and Grant, R. L., Loss of minerals through the skin of normal humans when sweating is avoided. J. Clin. Invest., 1937, 16, 729.

31. Dahl, L. K., Stall, B. G., III, and Cotzias, G. C., Metabolic effects of marked sodium restriction in hypertensive patients. Skin electrolyte losses. J. Clin. Invest., 1955, 34, 462.

32. Danowski, T. S., Tarail, R., Peters, J. H., Weigand, F. A., Mateer, F. M., and Greenman, L., Fecal electrolytes and nitrogen during cortisone or ACTH therapy. Proc. Soc. Exper. Biol. \& Med., 1952, 81, 445.

33. Moore, F. D., Boling, E. A., Ditmore, H. B., Jr., Sicular, A., Teterick, J. E., Ellison, A. E., Hoye, S. J., and Ball, M. R., Body sodium and potassium. V. The relationship of alkalosis, potassium deficiency and surgical stress to acute hypokalemia in man. Metabolism, 1955, 4, 379.

34. Falbriard, A., Muller, A. F., Neher, R., and Mach, R. S., Etude des variations de l'aldostéronurie sous l'effet de surcharges en potassium et de déperditions rénales et extrarénales de sel et d'eau. Schweiz. med. Wchnschr., 1955, 85, 1218.

\section{SPECIAL NOTICE TO SUBSCRIBERS}

Post Offices will no longer forward the Journal when you move.

Please notify The Journal of Clinical Investigation, Business Office, 333 Cedar Street, New Haven, Conn. at once when you have a change of address, and do not omit the zone number if there is one. 